\title{
From the Co-Editors
}

Dear Dear JSESD Readers and Supporters,

About five years ago, we moved the Journal of Science Education for Students with Disabilities (JSESD) to an online and open access journal. Having JSESD in this format maximizes access for readers and authors, will help the journal continue to grow, and will allow the journal to remain economically sustainable. The results of this move have been positive- though we always seek ways to improve the journal offering, reach a greater membership, and solicit a greater number of quality manuscripts. To this end, JSESD has migrated to a new journal management system, hosted by bepress Digital Commons. All of JSESD's archived content will be moved to the new system for long-term preservation.

This professional-grade system:

- Allows authors to manage article submissions by tracking articles through the peer review process

- Optimizes search engine discoverability for individual articles

- Provides sophisticated reports on article download metric

- AND provides unlimited customer support

The move to the improved system was made possible by the very talented group at RIT's Scholarly Publishing Studio led by Nicholas Paulus and Eric MacArthur. This team has proved very competent in making sure that the journal is published with attention to quality. Through their guidance, the logistics of maintaining the journal (from receipt of manuscripts, to layout, and publication) has improved dramatically. With their help, we are confident that we will be able to move a submitted article through the publication process in a timely manner for authors.

A couple reminders:

- The journal will reside online and free-of-charge on Rochester Institute of Technology's (RIT)
Wallace Library server, and can be found at http://scholarworks.rit.edu/jsesd/.

- Online submissions are preferred at http://scholarworks.rit.edu/jsesd/. However, submissions can still be sent to the co-editors (1kq9999@rit.edu \& tepnts@rit.edu).

We continue to work diligently to improve JSESD. One of the largest challenges to the journal remains the solicitation of manuscript submissions. As such, we are asking the journal's readership to assist us in advertising the journal. If you are familiar with individuals who might be interested in submitting a manuscript, please pass along the JSESD author link provided above.

We are especially interested in articles on science education for students with varying types of disabilities and at a full range of grade levels (K-12 and postsecondary).

We believe that there is a considerable amount of high quality scholarship that is being conduction in the field if science education for students with disabilities. We are pleased to be a mechanism for the dissemination of such efforts and are eager to grow to accommodate even more submissions.

As always, we appreciate your support in maintaining JSESD as a quality peer-reviewed journal.

Sincerely,

\section{TODD PAGANO \& L.K. QUINSLAND}

Todd Pagano, Ph.D. \& L.K. Quinsland, Ph.D. Co-Editors, Journal of Science Education for Students with Disabilities

Rochester Institute of Technology/

National Technical Institute for the Deaf

About the JSESD cover: Cathy Chou (Prof. of Imaging Arts \& Sciences at RIT/NTID) created the JSESD cover. The background DNA image was strategically chosen to symbolize the interplay of JSESD's readership; that of experts in various fields of disabilities along with experts in the disciplines of science. The two intertwined sides of the double helix backbone represent this relationship. The rungs of the DNA structure represent the various age groups (K-Postsecondary) of students upon which this journal focuses. 